\title{
EVALUATION OF ESTIMATED DIRECT HEALTH EXPENSES ON TOBACCO- AND ALCOHOL-RELATED DISEASES IN CONTEXT OF EXCISE TAXES REVENUES IN THE CZECH REPUBLIC
}

\author{
Gabriela Kukalová1, Lukáš Moravec ${ }^{1}$, Dana Bína Filipová1, Lenka Kučírková2 \\ 'Department of Trade and Finance, Faculty of Economics and Management, Czech University of Life Sciences Prague, Prague, Czech Republic \\ 2Department of Languages, Faculty of Economics and Management, Czech University of Life Sciences Prague, Prague, Czech Republic
}

\begin{abstract}
SUMMARY
Objectives: This article deals with the comparison of excise tax revenues from alcoholic beverages and tobacco products with public spending that are spent on treating diseases occurring in consumers of these commodities.

Methods: Based on available data, the study estimates direct public expenditures on the treatment of tobacco-related diseases and very frequent alcohol consumption-related diseases in the Czech Republic. These partial results are evaluated in the context of tax revenues from consumption of the mentioned commodities. The analysis works with the data from 1998-2017, which was obtained from the Ministry of Health of the Czech Republic, the National Institute of Public Health, the Customs Administration of the Czech Republic, the Ministry of Finance of the Czech Republic, and the Czech Statistical Office.

Results: Medical treatment costs of smoking-related diseases were 18.35-48.19 billion CZK per year in the analysed period. These expenditures in the period 1998-2011 exceeded the annual revenues from the tax on tobacco products (in 2002 by 12.08 billion CZK). Since 2012, the balance has been positive in favour of public spending. Expenditures on the treatment of alcohol-related diseases amounted to 9.66-25.36 billion CZK per year in the given period, the expenditures, except the year 1998, exceeded the revenues from alcoholic beverages taxes (by 14.63 billion CZK in 2009).

Conclusions: The study shows that the excise tax revenues for tobacco products do not reach the level of healthcare spending for tobacco-related disease in the most of the analysed period, and this difference increases with the length of consumption, which can be interpreted in such a way that current excise tax revenues potentially mean public healthcare expenditures, which cumulatively exceed revenues from the relevant excise duties.
\end{abstract}

Key words: tax revenue, excise taxes, health financing, alcohol, tobacco

Address for correspondence: L. Moravec, Czech University of Life Sciences Prague, Faculty of Economics and Management, Department of Trade and Finance, Kamýcká 129, 16521 Prague, Czech Republic. E-mail: moravec@pef.czu.cz

https://doi.org/10.21101/cejph.a5538

\section{INTRODUCTION}

Revenues from excise taxes are one of the substantial revenues of the state budget of the Czech Republic. Established here are taxes on mineral oils, taxes on ethyl alcohol, beer, wine and intermediates products (alcoholic beverages), and taxes on tobacco products (1). Excise taxes are levied selectively on selected commodities, primarily with the aim to reduce their consumption. An important aspect of reducing the consumption of specific product groups is their impact on the health of the population.

According to available sources, approximately $30 \%$ of the adult population in the Czech Republic are long-term smokers. The proportion of smokers in the adult population (15 years of age and over) is the subject of a number of studies regularly published by the National Institute of Public Health. The proportion of smokers (including occasional) has been in the range of $28-32 \%$ in recent years (2). In 2012-2016 the share of smokers was $24.1-31.4 \%$ (3). In the researched period the trend of share of smokers was decreasing. The share of smokers in 2016 was in total $28.6 \%$ which, opposing to 2015 (24.1\%), meant a statistically important increase by $4.5 \%$. However, a slight decrease was noticeable in comparison with 2014: by $2.8 \%$ (3). The trend within 2012-2018 was also decreasing. The share of smokers in 2017 was $25.2 \%$, then it rose in 2018 to $28.5 \%$, but there still was a slight decrease by $2.9 \%$ in comparison with 2014 (4). The share of alcohol consumers in the population of the Czech Republic is also the subject of regular studies. Alcohol consumption in the Czech Republic is about $85 \%$ of the adult population (in consumer categories: moderate drinking, hazardous drinking and harmful drinking). The share of whole-life non-drinkers in the adult population was $2.55 \%$ in 2012 , then $3.8 \%$ in 2016 , and $3.7 \%$ in 2018 . The share of very frequent alcohol consumers (consumer category: hazardous and harmful drinking) was $13.99 \%$ in 2012 (5), 13.2\% in 2014 (6), and $17.6 \%$ in 2016 (3). The Ministry of Health of the Czech Republic shows the share of very frequent alcohol consumers in the adult population in the extent of $15 \%$ (7).

Excise taxes should also reduce the consumption of alcoholic beverages and tobacco products. In the Czech Republic, there 
are taxes on ethyl alcohol, beer, wine and intermediates products (alcoholic beverages), and taxes on tobacco products. Taxes on alcoholic beverages and tobacco products exist in a number of countries, and in the European Union excise duties are subject to harmonization, such as a minimum tax rate on cigarettes. A number of research studies focus primarily on the income from these taxes and on the impact of changes in tax rates. Tobacco tax rates are increasing almost every year within the European Union. The model (181 countries) of calculation of the impact of consumption tax increase by 1 USD was created. (8). The findings support the public health benefit of tobacco tax increases (9). An increase in the tobacco tax has also taken place recently for example in China. The increase in the resulting tax rate as a percentage of the retail price from $49 \%$ to $56 \%$ is still relatively low compared to the WHO-recommended benchmark, which is about $70 \%$ of the retail price (10).

Increasing the tax rate means increasing the price of tobacco products or alcoholic beverages. The consequences of these changes are often examined in terms of consumption reduction and changes in consumer behaviour. Studies published on this topic usually indicate a reduction in consumption as a result of increased tax rates and price increases. A different study investigated the effects of price hikes on cigarette consumption, tobacco tax revenues, and reduction in smoking-caused mortality in 36 African countries (11). The administered simulation showed that with an average annual cigarette price increase of $7.38 \%$, the average annual cigarette consumption would decrease by $3.84 \%$, and the average annual tobacco tax revenue would increase by $19.39 \%$ (11). A similar study was also carried out in 28 countries of the European Union. The results of the simulated analysis showed that a rise of $10 \%$ in the cigarette price would significantly reduce cigarette consumption as well as the total death toll caused by smoking in all the observed countries, but would be the most effective in Bulgaria and Romania, followed by Latvia and Poland (12). Tobacco taxes are the most cost-effective way to reduce the tobacco use, especially among the youth and low-income people. A tax increase that increases tobacco prices by $10 \%$, decreases tobacco consumption by about $4 \%$ in high-income countries and about $5 \%$ in low- and middle-income countries (13). Taxes on alcohol increase its price and thus can be a powerful lever for influencing alcohol consumption and problems, even if the purpose of those taxes is primarily to raise revenues and not necessarily to improve health (14). However, research studies of the real behaviour of tobacco and alcohol consumers often indicate that the consumption of these commodities after tax and price increases does not change much (15).

However, those articles do not indicate alcohol and tobacco tax revenues in the context of costs that must be spent on the treatment of consumers of these commodities. This issue is dealt by further studies. The reduction in the number of tobacco and alcohol stores in New Zealand caused among others the reduction of healthcare costs by 1.23 billion USD (16). An increase in the tobacco tax would lead to savings in the health sector (17). Another study deals with the global economic difference between tobacco tax receipts and the economic costs of smoking-attributable diseases (18). Tobacco tax increases deliver sizeable health gains and health sector cost savings (19). A comparison of revenues from the tax on tobacco products and expenses on the treatment of smokers is described in a study researched for Philip Morris CR (20). A dif- ferent study shows that it is proved that taxes have been shown to generate significant health gains when applied to tobacco products and alcoholic beverages (21).

The aim of this research paper is to evaluate the amount of excise tax revenues from alcohol and tobacco products in the context of the direct public costs spent for the treatment of diseases occurring in consumers of these commodities in the Czech Republic. The direct public cost of treating diseases caused by the negative effects of tobacco products and alcoholic beverages is not part of any official statistics in the Czech Republic nor published by any institution. For this reason we created our own method of estimating the relevant costs, which is applied in this research study.

Studies and publications dealing with the quantification of costs in connection with tobacco and alcohol consumption in the Czech Republic are often very different. Some studies included only the cost of treatment of alcohol or tobacco addiction. They were for example costs for the treatment in the Centres for TobaccoDependent in 2012. Total expenses after the deduction of income amounted to $1,630,525 \mathrm{CZK}$; the cost of one successfully treated patient was 10,003 CZK. Apart from healthcare costs other studies included additional costs (22). Due to smoking and premature death caused by smoking during the year 2003, the state economy lost 64 billion CZK, with the revenues amounting to 49 billion CZK (23), total social costs of alcohol use of 16.36 billion CZK, and as regards tobacco the amount of 33.12 billion CZK (24).

\section{MATERIALS AND METHODS}

The analysis works with the data for the period 1998-2017. The relevant data was obtained from the Czech Statistical Office (CZSO) (25), the Ministry of Finance of the Czech Republic (MoF CR) (26) and the Customs Administration of the Czech Republic (CA CR) (1). As a basis for the assumption of expenditures for health care, the currently available numbers of smokers and very frequent alcohol consumers in the Czech Republic are used from the sources of the Ministry of Health of the Czech Republic $(\mathrm{MoH}$ CR) (7), the Institute of Health Information and Statistics of the Czech Republic (IHIS) (27), and studies published by the National Institute of Public Health (NIPH) (2-6).

\section{Tax Revenues from Tobacco Products and Alcoholic Beverages}

For analysis purposes, the data on ethyl alcohol tax, beer tax, wine and intermediate products taxes, and tobacco taxes is relevant $(1,26)$. The tax revenue from tobacco products per calendar year is the sum of revenues for individual months of the year (Table 1). Revenue from ethyl alcohol tax, beer tax and wine and intermediate products tax are listed together as alcoholic beverages taxes (Table 1).

\section{Numbers of Smokers and Very Frequent Alcohol Consumers}

Based on the available data on the proportion of smokers and alcohol users in the adult population (15 years of age and over), the number of smokers and the number of so-called very frequent alcohol consumers were determined. To provide more clarity the 
Table 1. Revenues from tobacco products and alcoholic beverages taxes (1998-2017)

\begin{tabular}{|c|c|c|c|}
\hline Year & $\begin{array}{l}\text { Revenues from tobacco products taxes } \\
\text { (thousand CZK) }\end{array}$ & $\begin{array}{l}\text { Revenues from alcoholic beverages taxes } \\
\text { (thousand CZK) }\end{array}$ & $\begin{array}{l}\text { Total revenues from tobacco products } \\
\text { taxes and alcoholic beverages taxes } \\
\text { (thousand CZK) }\end{array}$ \\
\hline 1998 & $14,204,244$ & $10,660,528$ & $24,864,772$ \\
\hline 1999 & $15,647,175$ & $10,521,203$ & $26,168,378$ \\
\hline 2000 & $14,938,870$ & $9,620,399$ & $24,559,269$ \\
\hline 2001 & $13,194,000$ & $10,246,777$ & $23,440,777$ \\
\hline 2002 & $15,773,581$ & $9,699,674$ & $25,473,255$ \\
\hline 2003 & $17,676,964$ & $9,410,151$ & $27,087,115$ \\
\hline 2004 & $21,524,847$ & $9,154,709$ & $30,679,556$ \\
\hline 2005 & $25,427,905$ & $9,642,348$ & $35,070,253$ \\
\hline 2006 & $32,241,538$ & $10,668,289$ & $42,909,826$ \\
\hline 2007 & $46,997,607$ & $11,120,489$ & $58,118,096$ \\
\hline 2008 & $37,506,532$ & $10,982,108$ & $48,488,640$ \\
\hline 2009 & $37,704,057$ & $10,729,377$ & $48,433,434$ \\
\hline 2010 & $42,467,316$ & $11,145,123$ & $53,612,439$ \\
\hline 2011 & $44,957,956$ & $11,569,679$ & $56,527,635$ \\
\hline 2012 & $47,001,889$ & $11,487,330$ & $58,489,219$ \\
\hline 2013 & $46,873,259$ & $11,179,911$ & $58,053,170$ \\
\hline 2014 & $44,789,501$ & $11,642,267$ & $56,431,768$ \\
\hline 2015 & $50,863,600$ & $12,185,023$ & $63,048,623$ \\
\hline 2016 & $54,415,700$ & $12,159,041$ & $66,574,741$ \\
\hline 2017 & $56,219,300$ & $12,377,266$ & $68,596,566$ \\
\hline
\end{tabular}

Source: Czech Statistical Office (1), Ministry of Finance of the Czech Republic (26)

number of adult population can be seen in Table 2, which contains the results of analysis about numbers of smokers and very frequent alcohol consumers. Two consumption categories: hazardous drinking and harmful drinking belong to the very frequent alcohol consumers $(3,5,6)$. The number of smokers in single years is based on the data on the proportion of smokers in the adult population of the Czech Republic $(2,3)$. For the purpose of our study, the proportion of smokers was set at $30 \%$ in all years of the reference period. The number of very frequent alcohol consumers was determined on the basis of the share of these people in the adult population of the Czech Republic. The daily intake of 40 to 60 grams for men and 20 to 40 grams for women is considered hazardous drinking and the average daily consumption over 60 grams for men and 40 grams for women is considered harmful (3). According to the $\mathrm{MoH} \mathrm{CR}$, the share of very frequent alcohol consumers in the adult population is $15 \%$ (7). Studies published in the period 2013-2017 by the NIPH showed the share of very frequent alcohol consumers in the range of $13.2-17.6 \%(3,5,6)$.

The $15 \%$ share of very frequent alcohol consumers in the adult population was used for the purposes of calculations in our study. In order to obtain the total number of smokers and very frequent alcohol consumers, it must be taken into account that some of these people are also very frequent alcohol users and smokers at the same time. According to published studies $(3,5,6)$, in the consumer category of hazardous drinking there are $39.5-46.4 \%$ of smokers and in the category of harmful drinking 52-59.06\% of smokers. Based on the calculations that take into account these proportions, it was determined that the proportion of smokers is
$49 \%$ (of the number of very frequent alcohol consumers). The total number of smokers and very frequent alcohol consumers is defined as follows: number of smokers $(30 \%$ of the adult population $)+$ number of very frequent alcohol drinkers $(15 \%$ of the adult population) - number of very frequent alcohol consumers and smokers at the same time (49\% from the number of very frequent alcohol consumers).

\section{Expenditures on Treatment of Tobacco-Related and Alcohol-Related Diseases}

The IHIS states that public healthcare expenditures are considered (in the conditions of the Czech Republic) expenditures from the state budget and regional budgets (budgets of districts and municipalities), and also expenditures of the public healthcare insurance system (of public health insurance companies). Furthermore, the structure of public healthcare expenditures is shown here (27).

In connection with the analysis of the costs of treatment of tobacco-related diseases, the most frequent tobacco-related diseases were selected. These include chronic lung diseases, which account for $75 \%$ of tobacco and tobacco use. Cancerous diseases are also included: lung cancer ( $90 \%$ share of smoking in the occurrence of the disease), ureter and urinary bladder cancer (60\%), cervical cancer $(30 \%)$, and pancreatic cancer $(30 \%)$. The other most common diseases caused by smoking are heart and vascular diseases (25\%) (28). After counting the frequency of these types of diseases, it was determined that these diseases were on average by $44.87 \%$ caused by smoking. These diseases can be classified into 
4 main groups according to the Anatomical Therapeutic Chemical (ATC) classification system: Respiratory system, Genito-urinary system and sex hormones, Alimentary tract and metabolism, Cardiovascular system. From available sources, it was not possible to obtain the data on the total costs of the treatment and drug expenditures of individual types of diseases, so the ATC classification system was used. Subsequently, the data on the share of expenditures of each ATC group in the total drug expenditures was used $(27,29)$. By analogy, this share was transferred as the share of total public expenditures on the health care (average share of expenditures for 1998-2017). The individual groups of diseases are involved in the following expenditures: Respiratory system $8.18 \%$, Genito-urinary system and sex hormones $5.84 \%$, Alimentary tract and metabolism $11.66 \%$, and Cardiovascular system $16.49 \%$ ( $42.17 \%$ in total). After calculating the share of smoking in the most common diseases, it was determined that the public expenditures on the health care (in the adult population) was $19 \%$ due to consumption of tobacco products.

The estimates of spending on the treatment of very frequent alcohol users were made on the basis of available studies and published expert articles. Excessive consumption of alcoholic beverages often leads to mental health disorders. In addition to depression and brain damage, it also affects physical health. Most often, the digestive system is damaged due to the disruption of liver and kidney function. Alcohol affects in fact all the body organs. Average consumption of more than one standard beverage (small beer or $1 \mathrm{dl}$ of wine) per day increases the risk of the development of overwhelming majority of diseases and death (30). Direct public expenditures on the health care have been recalculated to people who are very frequent alcohol consumers (15\% of the adult population). It is taken into account that up to one third of common diseases occur regardless of alcohol consumption (31). As there is a lack of other valid research sources, the analysis is based on the assumption that $2 / 3$ of alcohol-related diseases are caused by very frequent consumption of alcohol.

The revenues from the excise taxes in question were subsequently compared with the treatment costs of the treatment of tobacco-related diseases and alcohol-related diseases caused by very frequent consumption of alcohol. The comparison is done primarily in terms of time harmony; here it is focused on the cash flow in individual years of the surveyed period. In the next part of the study, it was taken into account that the effects of smoking and alcohol consumption would become apparent after a certain period of time. Tax revenues and treatment costs were therefore compared in time mismatch. With regard to the fact that no specific expert estimation of the duration when the abovementioned diseases caused by smoking and very frequent alcohol consumption appear, time lag of 5,10 and 15 years has been established. Tax revenues in the year $\mathrm{x}$ were compared to

Table 2. Number of smokers and very frequent alcohol consumers in adult population (1998-2017)

\begin{tabular}{|c|c|c|c|c|c|}
\hline Year & $\begin{array}{c}\text { Number } \\
\text { of adult population }\end{array}$ & Number of smokers & $\begin{array}{l}\text { Number of very } \\
\text { frequent alcohol } \\
\text { consumers }\end{array}$ & $\begin{array}{l}\text { Number of very frequent } \\
\text { alcohol consumers be- } \\
\text { ing smokers } \\
\text { concurrently }\end{array}$ & $\begin{array}{l}\text { Total number of smokers } \\
\text { and very frequent } \\
\text { alcohol consumers }\end{array}$ \\
\hline 1998 & $8,538,150$ & $2,561,445$ & $1,280,723$ & 627,554 & $3,214,613$ \\
\hline 1999 & $8,570,893$ & $2,571,268$ & $1,285,634$ & 629,961 & $3,226,941$ \\
\hline 2000 & $8,602,112$ & $2,580,634$ & $1,290,317$ & 632,255 & $3,238,695$ \\
\hline 2001 & $8,584,574$ & $2,575,372$ & $1,287,686$ & 630,966 & $3,232,092$ \\
\hline 2002 & $8,613,503$ & $2,584,051$ & $1,292,025$ & 633,092 & $3,242,984$ \\
\hline 2003 & $8,656,980$ & $2,597,094$ & $1,298,547$ & 636,288 & $3,259,353$ \\
\hline 2004 & $8,693,361$ & $2,608,008$ & $1,304,004$ & 638,982 & $3,273,050$ \\
\hline 2005 & $8,749,748$ & $2,624,924$ & $1,312,462$ & 643,106 & $3,294,280$ \\
\hline 2006 & $8,807,765$ & $2,642,330$ & $1,321,165$ & 647,371 & $3,316,124$ \\
\hline 2007 & $8,904,207$ & $2,671,262$ & $1,335,631$ & 654,459 & $3,352,434$ \\
\hline 2008 & $8,987,535$ & $2,696,261$ & $1,348,130$ & 660,584 & $3,383,807$ \\
\hline 2009 & $9,012,443$ & $2,703,733$ & $1,351,866$ & 662,415 & $3,393,185$ \\
\hline 2010 & $9,014,627$ & $2,704,388$ & $1,352,194$ & 662,575 & $3,394,007$ \\
\hline 2011 & $8,964,204$ & $2,689,261$ & $1,344,631$ & 658,869 & $3,375,023$ \\
\hline 2012 & $8,955,829$ & $2,686,749$ & $1,343,374$ & 658,253 & $3,371,870$ \\
\hline 2013 & $8,934,964$ & $2,680,489$ & $1,340,245$ & 656,720 & $3,364,014$ \\
\hline 2014 & $8,937,230$ & $2,681,169$ & $1,340,584$ & 656,886 & $3,364,867$ \\
\hline 2015 & $9,020,834$ & $2,706,250$ & $1,353,125$ & 663,031 & $3,396,344$ \\
\hline 2016 & $9,103,928$ & $2,731,178$ & $1,365,589$ & 669,139 & $3,427,629$ \\
\hline 2017 & $8,939,378$ & $2,681,813$ & $1,340,907$ & 657,044 & $3,365,676$ \\
\hline
\end{tabular}

Source: Sovinová et al. (2), Váňová et al. (3), Csémy et al. (4), Sovinová and Csémy (5), Sovinová and Csémy (6), Ministry of Health of the Czech Republic (7), Czech Statistical Office (25) 
spending for the treatment of tobacco-related and alcohol-related diseases in the year $\mathrm{x}+5, \mathrm{x}+10$ or $\mathrm{x}+15$.

\section{RESULTS}

The number of smokers and very frequent alcohol consumers was calculated based on the data about adult population of the Czech Republic and the share of smokers and very frequent alcohol consumers of the adult population (Table 2). Also, the total number of smokers and very frequent alcohol consumers was calculated (Table 2).

On the basis of the analyses, an estimation of direct public expenditures on health care for smokers and very frequent alcohol consumers was made (Table 3 ). The total direct public expenditures for both groups is the sum of expenditures for individual groups. In this case, it would be inappropriate to deduct spending on the treatment of very frequent alcohol users and smokers, because in this group diseases associated with smoking and very frequent alcohol consumption can occur (Table 3).

Tax revenues from tobacco products and alcoholic beverages were compared with spending on the treatment of tobacco-related diseases and alcohol-related diseases caused by very frequent consumption of alcohol. Differences are released in time harmony (Figures 1, 2 and 3).
The difference between the tobacco products tax revenues and the costs of the treatment for tobacco-related diseases shows certain development, especially in connection with the change in the rate of cigarette tax. Tax revenues from tobacco products were lower than treatment costs of smokers in the period 1998-2011. The exception was the year 2007, when there was a significant increase in tax revenues. This was due to the fact that since 2008 the tax rate for tobacco products has been considerably higher and, therefore, the purchases of cigarette stocks increased in 2007 and due to this the tax revenues increased. The gradual increase in the tax rate for tobacco products in the following years reduced the difference between the tax revenues and treatment expenditures for tobacco-related diseases. Since 2012 the mentioned difference has been positive, it means that tobacco tax revenues exceed the cost of treating tobacco-related diseases. The highest negative difference between revenues and expenditures was recorded in 2002, amounting to -12.08 billion CZK, while in the year 2017, the revenues exceeded the expenditure on the treatment by 12.44 billion CZK (Fig. 1).

Revenues from alcoholic beverages taxes increased by only 16\% between 1998 and 2017. In 1998 the revenue was 10.66 billion CZK, in 2017 it was 12.38 billion CZK. The increase in rates took place several times mainly on the alcohol tax. In spirits, especially since 2010 , the consumption has fallen, in the value of $100 \%$ alcohol the consumption was 3.3 litres per capita in 1998,

Table 3. Public health expenditures on curing of diseases potentially caused by smoking and very frequent alcohol consumption (1998-2017)

\begin{tabular}{|c|c|c|c|c|}
\hline Year & $\begin{array}{c}\text { Public expenditure on health } \\
\text { - adults } \\
\text { (thousand CZK) }\end{array}$ & $\begin{array}{l}\text { Public expenditure on health - } \\
\text { smoking adults } \\
\text { (thousand CZK) }\end{array}$ & $\begin{array}{l}\text { Public expenditure on health } \\
\text { - very frequent adult alcohol } \\
\text { consumers } \\
\text { (thousand CZK) }\end{array}$ & $\begin{array}{c}\text { Public expenditure on health } \\
\text { total - smoking adults and } \\
\text { very frequent adult alcohol } \\
\text { consumers } \\
\text { (thousand CZK) }\end{array}$ \\
\hline 1998 & $96,580,885$ & $18,350,368$ & $9,658,088$ & $28,008,457$ \\
\hline 1999 & $111,310,723$ & $21,149,037$ & $11,131,072$ & $32,280,110$ \\
\hline 2000 & $115,615,611$ & $21,966,966$ & $11,561,561$ & $33,528,527$ \\
\hline 2001 & $129,283,148$ & $24,563,798$ & $12,928,315$ & $37,492,113$ \\
\hline 2002 & $146,607,204$ & $27,855,369$ & $14,660,720$ & $42,516,089$ \\
\hline 2003 & $154,450,803$ & $29,345,653$ & $15,445,080$ & $44,790,733$ \\
\hline 2004 & $169,416,491$ & $32,189,133$ & $16,941,649$ & $49,130,782$ \\
\hline 2005 & $181,800,350$ & $34,542,066$ & $18,180,035$ & $52,722,101$ \\
\hline 2006 & $191,958,632$ & $36,472,140$ & $19,195,863$ & $55,668,003$ \\
\hline 2007 & $203,474,486$ & $38,660,152$ & $20,347,449$ & $59,007,601$ \\
\hline 2008 & $220,253,869$ & $41,848,235$ & $22,025,387$ & $63,873,622$ \\
\hline 2009 & $253,642,534$ & $48,192,082$ & $25,364,253$ & $73,556,335$ \\
\hline 2010 & $235,909,408$ & $44,822,788$ & $23,590,941$ & $68,413,728$ \\
\hline 2011 & $246,192,899$ & $46,776,651$ & $24,619,290$ & $71,395,941$ \\
\hline 2012 & $244,407,652$ & $46,437,454$ & $24,440,765$ & $70,878,219$ \\
\hline 2013 & $241,982,559$ & $45,976,686$ & $24,198,256$ & $70,174,942$ \\
\hline 2014 & $214,239,000$ & $40,705,410$ & $21,423,900$ & $62,129,310$ \\
\hline 2015 & $214,420,000$ & $40,739,800$ & $21,442,000$ & $62,181,800$ \\
\hline 2016 & $222,353,540$ & $42,247,173$ & $22,235,354$ & $64,482,527$ \\
\hline 2017 & $230,424,974$ & $43,780,745$ & $23,042,497$ & $66,823,242$ \\
\hline
\end{tabular}

Source: Czech Statistical Office (25), Institute of Health Information and Statistics of the Czech Republic (27) 


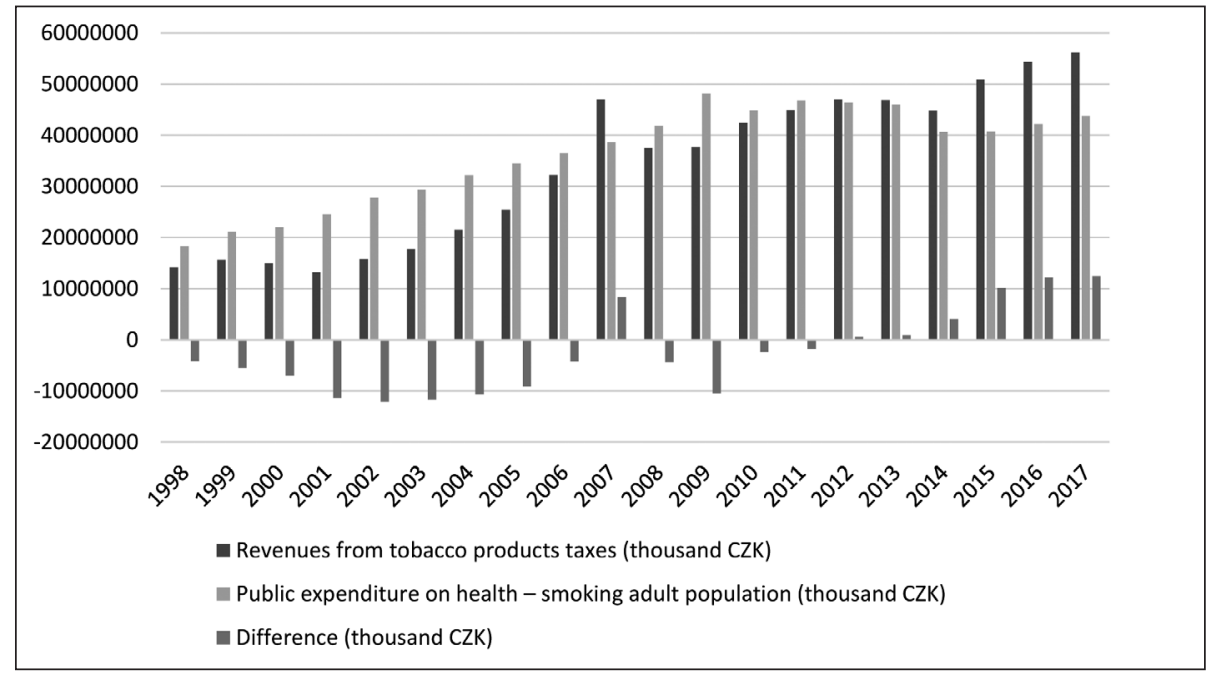

Fig.1. Difference between revenues from tobacco products taxes and tobacco-related illnesses cure expenses in the period 1998-2017.

Source: Customs Administration of the Czech Republic (2018), Ministry of Finance of the Czech Republic (2018); own elaboration

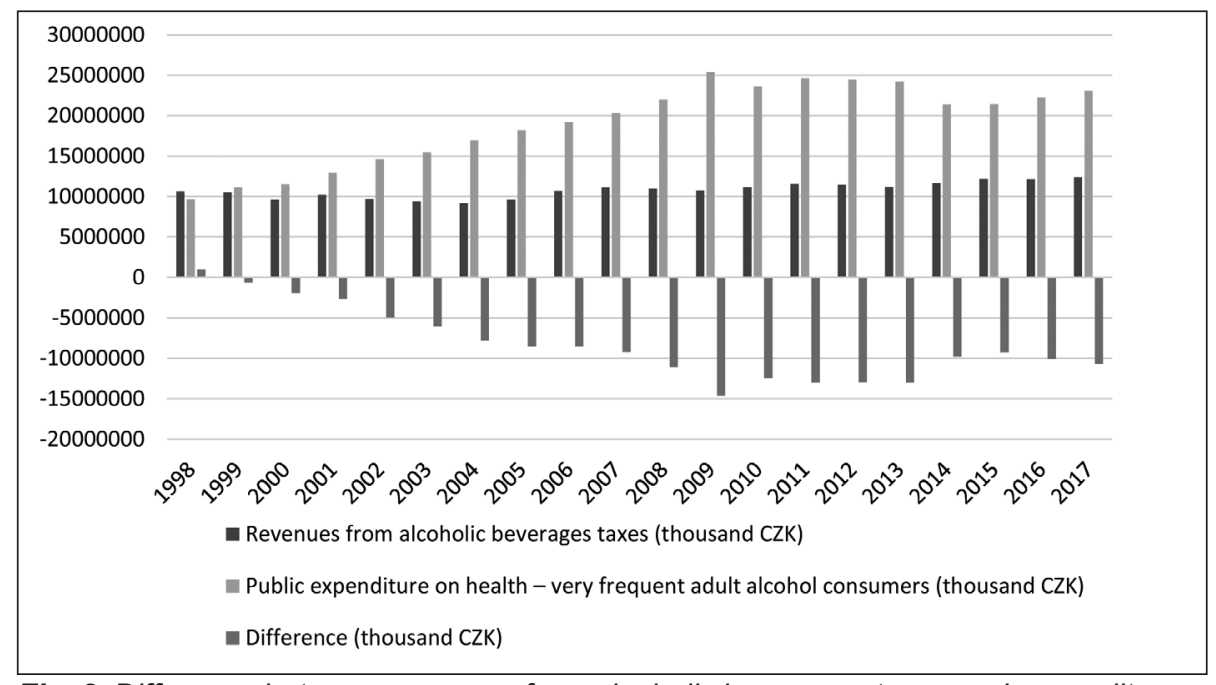

Fig. 2. Difference between revenues from alcoholic beverages taxes and expenditures on curing of illnesses related to the very frequent alcohol consumption in the period 1998-2017.

Source: Customs Administration of the Czech Republic (2018), Ministry of Finance of the Czech Republic (2018); own elaboration

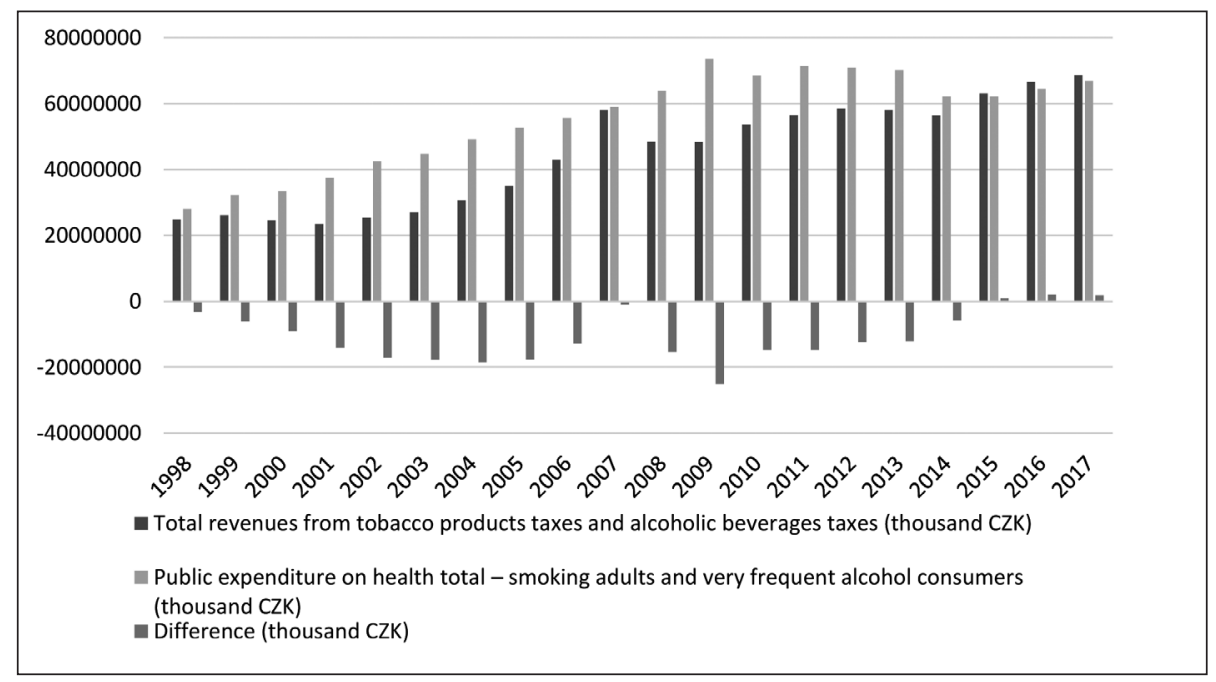

Fig. 3. Difference between the relevant excise taxes total revenues and the taxed commodities consumption-related illnesses treatment costs in the period 1998-2017.

Source: Customs Administration of the Czech Republic (2018), Ministry of Finance of the Czech Republic (2018); own elaboration 


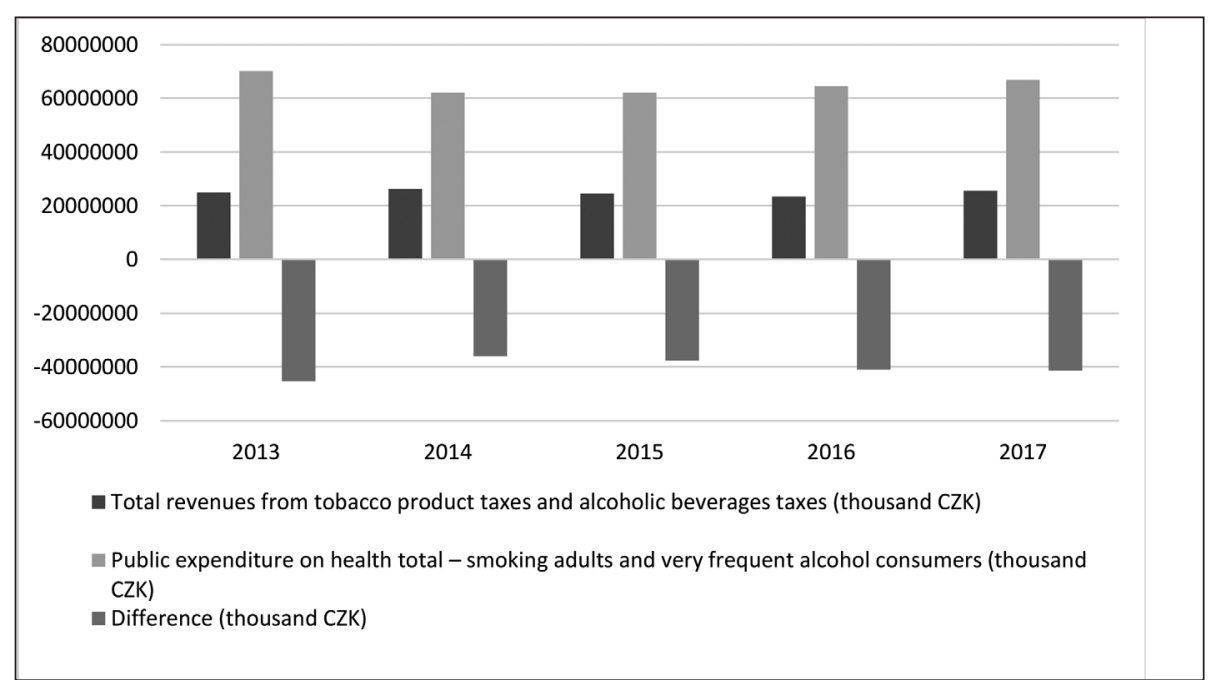

Fig. 4. Difference between the total revenues from tobacco products taxes and alcoholic beverages taxes and the taxed commodities consumption-related illnesses treatment costs: 5-year cash-flow lag.

Source: Customs Administration of the Czech Republic (2018), Ministry of Finance of the Czech Republic (2018); own elaboration

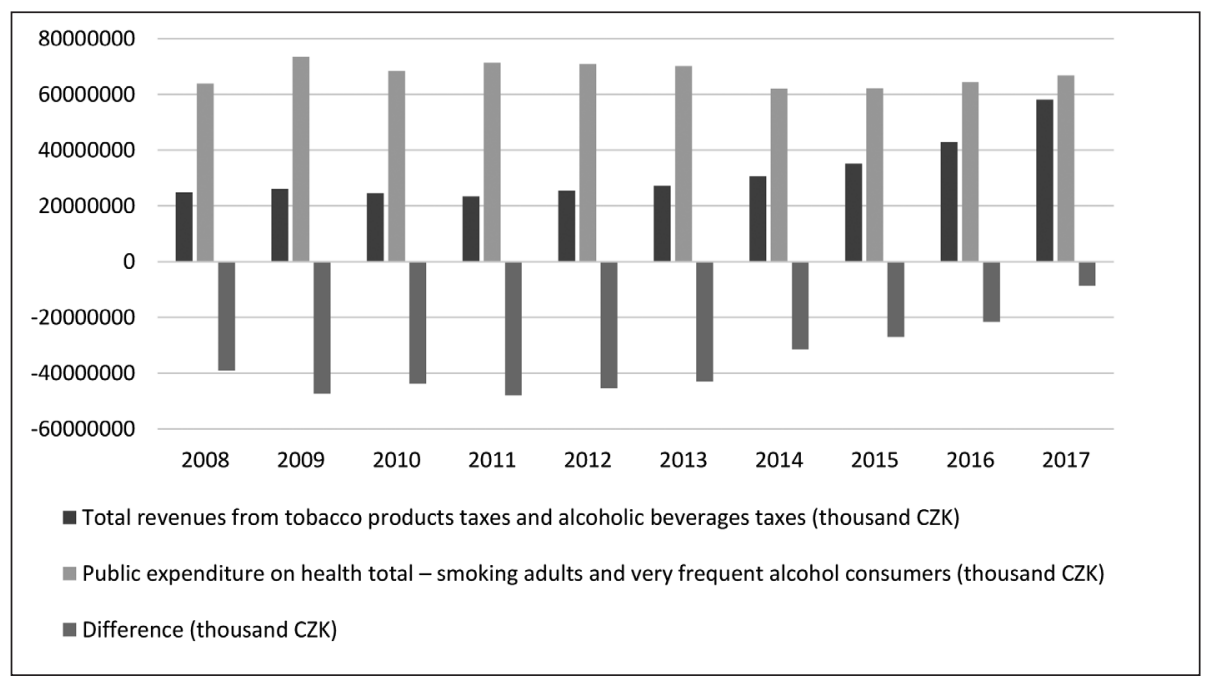

Fig. 5. Difference between the total revenues from tobacco products taxes and alcoholic beverages taxes and the taxed commodities consumption-related illnesses treatment costs: 10-year cash-flow lag.

Source: Customs Administration of the Czech Republic (2018), Ministry of Finance of the Czech Republic (2018); own elaboration

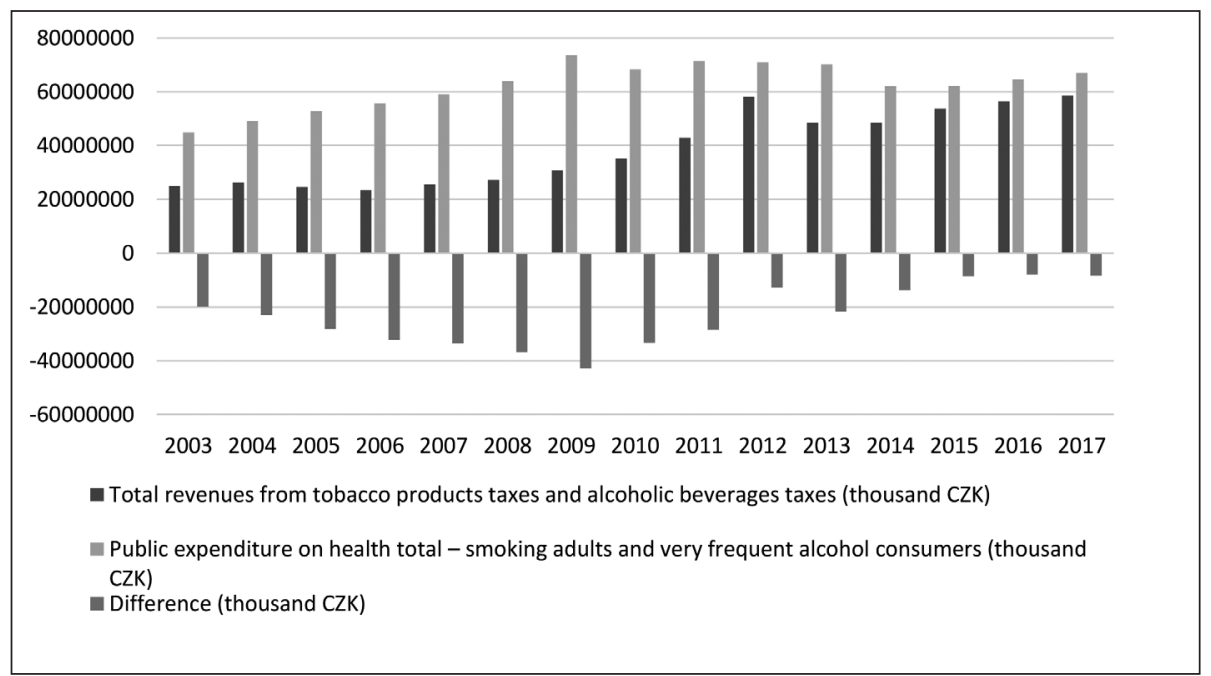

Fig. 6. Difference between the total revenues from tobacco products taxes and alcoholic beverages taxes and the taxed commodities consumption-related illnesses treatment costs: 15-year cash-flow lag.

Source: Customs Administration of the Czech Republic (2018), Ministry of Finance of the Czech Republic (2018); own elaboration 
in 2016 it was 2.8 litres per capita. In contrast, the consumption of beer and wine increased. These alcoholic beverages did not affect the amount of alcohol tax revenues because the tax rate was low (the silent wine tax was zero) and did not almost change during the reference period. A positive difference in the revenues from these taxes and the expenses for the treatment of alcoholrelated diseases (caused by very frequent alcohol consumers) was recorded only in 1998 in the amount of 1 billion CZK, in the following years the difference was always negative. The highest negative difference was in 2009, amounting to -14.63 billion CZK. From 2014, the annual difference is approximately -10 billion CZK (Fig. 2).

Expenditures for the treatment of tobacco-related and alcoholrelated diseases in the period 1998-2014 exceeded each year the revenues from these excise taxes. The highest difference was in 2009 when spending was by 25.12 billion CZK higher than revenues. In the years 2015-2017, the revenues from the taxes in question were higher than the costs of treatment, in 2016 the difference was 2.09 billion CZK. This is mainly related to the regular increase in rates and thus also to the increase of the revenues from the tax on tobacco products (Fig. 3).

The following comparisons take into account the time lag between consumption (and related tax levy) and expenses for the treatment of the disease, which will take effect after a certain period of time. The differences are given in the time mismatch of 5 years (Fig. 1), 10 years (Fig. 2) and 15 years (Fig. 3). In all model situations, spending on the treatment is higher than the total tobacco and alcoholic beverages tax revenues.

In case of a 5-year lag between the income from these taxes and treatment costs, the evident highest negative difference was in 2009. The expenses for treatments are higher by 42.88 billion CZK compared to the income from the mentioned taxes from 2004 (Fig. 4). Assuming a 10-year time lag, the highest negative difference was in 2011, when expenditures were higher by 47.96 billion CZK compared to revenues from these taxes in 2001 (Fig. 5). A 15 -year time lag model between tax revenues and expenditures on the treatment costs shows significantly higher spending. Expenditures exceeded the revenues from the taxes in question by 35.96 to 45.31 billion CZK (Fig. 6).

\section{DISCUSSION}

The estimates of public expenditures on the treatment of tobacco-related and alcohol-related diseases include only direct public expenditures on the health care. The estimates do not include social costs or, as the case may be, benefits linked, for example, to savings in the retirement scheme in case of premature deaths of smokers and alcoholics, nor the costs associated with, for example, the accidents caused by alcohol consumption or the costs of fighting fire set by smokers. Differences in the estimates arise mainly due to the fact that there are no statistics that would link direct or indirect costs to smoking or alcohol consumption. However, these estimates are always in the tens of billions of CZK per year $(23,24,32)$.

The direct public expenditures on the treatment of smokingrelated diseases in the period 1998-2017 were estimated to be between 18.35 CZK and 48.19 billion CZK per year. Over the last 10 years (2008-2017), these direct public expenditures amounted to more than 40 billion CZK annually. A different study states that total costs, including indirect costs, linked to smoking in the Czech Republic in 2000 amounted to about 77-103 billion CZK, which in the year 2000 signified about $3.6-4.8 \%$ of GDP (32). One smoker in the Czech Republic therefore cost at least 23-31 thousand CZK in 2000. The estimated expenditures on smokers' treatment in our study reached 21.98 billion CZK. A more comprehensive estimate of total social costs includes direct and indirect costs of the tobacco use in 2007 in the amount of 33.12 billion CZK (24). The estimates of direct public expenditures on the treatment of smokers in the given year amounted to 38.66 billion CZK in our study. The direct public expenditures for the treatment of diseases related to very frequent consumption of alcohol during the analysed period amounted from 9.66 billion CZK to 25.36 billion CZK. During the last ten years, these expenditures amounted to more than 20 billion CZK annually. According to the IHIS, the cost of treatment of alcohol dependence was 1.11 billion CZK in 2011 (this amount includes inpatient and outpatient care and medication) (27). According to our estimates, the treatment of diseases associated with very frequent alcohol consumption cost 24.62 billion CZK in that year.

In connection with the taxation of tobacco products and alcoholic beverages, it is generally stated that, compared to the direct public costs of the treatment for smokers and alcohol consumers, these revenues are higher, i.e., that smokers and very frequent alcohol users are profitable for the state. The results of our study and of other studies do not support this general assertion. The comparison of tobacco tax revenues and smokers' treatment expenditures shows that until 2011 the expenditures on smokers' treatment were higher than on tobacco tax revenues (the annual difference was 1.82-12.08 billion CZK). At the same time, a study commissioned by Philip Morris CR (19) states that in 1999 the balance of revenues and expenditures in the area of smoking was +5.815 billion CZK. The conclusions of the Phillip Morris study that smoking represents an economic benefit to the Czech state finances were criticised subsequently (33). Since 2012, the revenues have exceeded the expenses for the treatment of smokers, in 2017 the highest positive difference was recorded for direct public expenditures of 12.44 billion CZK. This difference in favour of public spending is mainly due to a significant increase in tax revenues from tobacco products as a result of regular increases in rates. Revenues from the tax on alcoholic beverages (except for 1998) were always significantly lower than the costs of treatment for very frequent alcohol consumers. At present, the difference is approximately 10 billion CZK annually (2016 and 2017).

Some studies only deal with the estimated costs of the treatment for smokers and alcohol consumers or compare these costs with the expenditures in that year. Moreover, in our study, we also focused on the important fact that diseases related to smoking and very frequent alcohol consumption would only take effect after some time. In case of time mismatch, the comparison of the total revenues from these taxes and total expenditures for the treatment is always disadvantageous for the state (and for public expenditures), the negative difference is up to several tens of billion of CZK per year, e.g., in a time gap of 15 years, 40 billion CZK. 


\section{CONCLUSIONS}

Based on the estimates of public spending on the health care for the treatment of smokers and very frequent alcohol consumers, it was found out that these expenditures amounted to tens of billion of CZK per year. Our study is about expenditures on the treatment of the most common diseases that occur in connection with smoking and very frequent alcohol consumption. In the period 1998-2017, expenditures on the treatment of tobacco-related diseases were between 18.35 and 48.19 billion CZK annually. The expenditures for the treatment of diseases of very frequent alcohol consumers in the same period were approximately half and amounted to over 9.66 billion CZK to 25.36 billion CZK. Total expenditures amounted to over 28.01 billion CZK to 73.55 billion CZK per year. If we compare the total revenues from these taxes with the total expenditures on the treatment of tobacco-related and alcohol-related diseases, then in the period 1998-2014, treatment costs were always higher than tax revenues. The highest overall difference was recorded in 2008, when treatment expenses were by 25.12 billion CZK higher than revenues from the taxes in question. In the period 2015-2017, the balance from the point of view of public finances was positive, according to estimates, the tax revenues were higher than the expenses for the treatment. As a part of our study, we also focused on the time lag between the year of tobacco and alcohol consumption (and tax levy), and the year of spending on diseases treatment which will only take effect after some time. Model assumptions have been made that revenues from excise duties associated with tobacco and alcohol consumption would be used for the treatment of tobacco-related and alcohol-related diseases after 5, 10 and 15 years. The results of the comparison in this time mismatch show the differences to the detriment of public finances.

\section{Acknowledgements}

This paper is a partial result of the research project No. 20181013 - Tax Laboratory Pilot Project Utilizing the Human Behaviour Research Unit of FEM CULS Prague, supported by the Internal Grant Agency (IGA) of Faculty of Economics and Management, CULS Prague.

\section{REFERENCES}

1. Customs Administration of the Czech Republic. Statistics [Internet] Prague: Customs Administration [cited 2018 May 19]. Available from: https:/www.celnisprava.cz/cz/dane/statistiky/Stranky/komentary.aspx. (In Czech.)

2. Sovinová H, Sadílek P, Csémy L. Development of the prevalence of smoking in the adult population of the Czech Republic, views and attitudes of Czech citizens on the issue of smoking (1997-2011). Research report. Prague: NIPH; 2012. (In Czech.)

3. Ván̆ová A, Skývová M, Csémy L. The use of tobacco and alcohol in the Czech Republic 2016. Prague: NIPH; 2017. (In Czech.)

4. Csémy L, Fialová A, Kodl M, Skývová M. The use of tobacco and alcohol in the Czech Republic 2018. Prague: NIPH; 2019. (In Czech.)

5. Sovinová H, Csémy L. The use of tobacco and alcohol in the Czech Republic 2012. Prague: NIPH; 2013. (In Czech.)

6. Sovinová H, Csémy L. The use of tobacco and alcohol in the Czech Republic 2014. Prague: NIPH; 2015. (In Czech.)

7. Ministry of Health of the Czech Republic. Support for the activities of the Ministry of Health in the area of tobacco products regulation and the results of research of the NIPH concerning the consumption of cigarettes and alcohol [Internet]. Prague: Ministry of Health of the Czech Republic; 2013 [cited 2018 Jul 15]. Available from: https://www.mzcr.cz/tiskovecentrum-mz/podpora-aktivit-mz-v-oblasti-regulace-tabakovych-vyrobku- a-vysledky-vyzkumu-szu-tykajici-se-konzumace-cigaret-a-alkoholu/. (In Czech.)

8. Goodchild M, Perucic AM, Nargis N. Modelling the impact of raising tobacco taxes on public health and finance. Bull World Health Organ. 2016;94(4):250-7.

9. Brock B, Choi K, Boyle RG, Moilanen M, Schillo BA. Tobacco product prices before and after a statewide tobacco tax increase. Tob Control. 2016;25(2):166-73.

10. Hu TW, Zhang XL, Zheng R. China has raised the tax on cigarettes: what's next? Tob Control. 2016;25(6):609-11.

11. Ho LM, Schafferer C, Lee JM, Yeh CY, Hsieh CJ. The effect of cigarette price increases on cigarette consumption, tax revenue, and smoking-related death in Africa from 1999 to 2013. Int J Public Health. 2017;62(8):899-909.

12. Yeh CY, Schafferer C, Lee JM, Ho LM, Hsieh CJ. The effects of a rise in cigarette price on cigarette consumption, tobacco taxationrevenues, and of smoking-related deaths in $28 \mathrm{EU}$ countries - applying threshold regression modelling. BMC Public Health. 2017;17:676. doi: 10.1186/ s12889-017-4685-x.

13. World Health Organization. Health topics: tobacco [Internet]. Geneva: WHO; 2019 [cited 2019 Dec 2]. Available from: https:/www.who.int/ news-room/fact-sheets/detail/tobacco.

14. World Health Organization. Global status report on alcohol and health. Geneva: WHO; 2018.

15. Li J, Newcombe R, Guiney H, Walton D. Impact on smoking behavior of the New Zealand annual increase in tobacco tax: data for the fifth and sixth year of increases. Nicotine Tob Res. 2017;19(12):1491-8.

16. Pearson AL, Cleghorn CL, van der Deen FS, Cobiac LJ, Kvizhinadze G, Nghiem N, et al. Tobacco retail outlet restrictions: health and cost impacts from multistate life-table modelling in a national population. Tob Control. 2017;26(5):579-85.

17. Salti N, Brouwer E, Verguet $S$. The health, financial and distributional consequences of increases in the tobacco excise tax among smokers in Lebanon. Soc Sci Med. 2016;170:161-9.

18. David P. Basic economic gap related to smoking: reconciling tobacco tax receipts and economic costs of smoking-attributable diseases. Tob Control. 2019;28(5):558-61.

19. Blakely T, Cobiac LJ, Cleghorn CL, Pearson AL, van der Deen FS, Kvizhinadze G, et al. Health, health inequality, and cost impacts of annual increases in tobacco tax: multistate life table modeling in New Zealand. PLoS Med. 2015;12(7):e1001856. doi: 10.1371/journal.pmed.1001856.

20. Little AD. Public finance balance of smoking in the Czech Republic. Report to Philip Morris CR a.s. [Internet]. Prague: Arthur D. Little International, Inc.; 2000 [cited 2018 Jun 27]. Available from: https:// www.tobaccofreekids.org/assets/content/what_we_do/industry_watch/ philip_morris_czech/pmczechstudy.pdf.

21. Sassi F, Belloni A. Fiscal incentives, behavior change and health promotion: what place in the health-in-all-policies toolkit? Health Promot Int. 2014;29(Suppl 1):103-12.

22. Králíková E, Kmet'ová A, Felbrová V, Kulovaná S, Rameš J, Štěpánková L, et al. Centers for Tobacco Dependents in the Czech Republic in 2012: overview, economy. Cas Lek Ces. 2014;153(5):246-50. (In Czech.)

23. Habrová D, Hrubá D. Economics of the smoking habit in the Czech Republic. Hygiena. 2007;52(4):110-4. (In Czech.)

24. Zábranský T, Běláčková V, Štefunková M, Vopravil J, Langrová M. Social costs of consuming alcohol, tobacco and illegal drugs in the Czech Republic in 2007. Prague: Centre for Addictology of the Psychiatric Clinic, First Faculty of Medicine, Charles University in Prague; 2011. (In Czech.)

25. Czech Statistical Office. Czech Republic since 1989 in figures 2017. Selected demographic data [Internet]. Prague: CZSO; 2018 [cited 2018 May 23]. Available from: https://www.czso.cz/documen ts/10180/61508910/32018118_0101.pdf/14cb0350-e7ce-44c4-a6ee5f53614c6b94?version=1.0. (In Czech.)

26. Ministry of Finance of the Czech Republic. Financial and customs activity reports [Internet]. Prague: Ministry of Finance of the Czech Republic [cited 2018 May 27]. Available from: https://www.mfcr.cz/cs/ verejny-sektor/dane/danove-a-celni-statistiky/zpravy-o-cinnosti-financnia-celni-sprav. (In Czech.)

27. Institute of Health Information and Statistics of the Czech Republic. Healthcare expenditures [Internet]. Prague: IHIS CR [cited 2018 May 23]. Available from: http://www.uzis.cz/category/tematicke-rady/ekonomikafinancni-analyzy/vydaje-na-zdravotnictvi. (In Czech.)

28. Králíková E, Kozák JT. How to stop smoking. 2nd ed. Prague: Maxdorf; 2003. (In Czech.) 
29. State Institute for Drug Control. Evaluation of distributed and dispensed medicinal products for 2017 [Internet]. Prague: State Institute for Drug Control, 2018 [cited 2018 Jul 20]. Available from: http://www.sukl.cz/ hodnoceni-distribuovanych-a-vydanych-lecivych-pripravku-za-2. (In Czech.)

30. Rehm J. The risk associated with alcohol use and alcoholism. Alcohol Res Health. 2011;34(2):135-43.

31. Nešpor K. Addictive behaviour and addiction: current findings and treatment perspectives. 3rd ed. Prague: Portál; 2007. (In Czech.)
32. Ross H, Havelková J. The economic impact of tobacco consumption and the possibilities of its reduction. Zdrav Cesk Repub. 2007;10(4):118-21. (In Czech.)

33. Ross H. Critique of the Philip Morris study of the cost of smoking in the Czech Republic. Nicotine Tob Res. 2004;6(1):181-9.

Received September 9, 2018 Accepted in revised form May 5, 2021 